\title{
Exports vs. Investment: How Political Discourse Shapes Popular Support for External Imbalances ${ }^{1}$
}

Federico Maria Ferrara $^{(a)}$, Jörg Stefan Haas ${ }^{(b)}$, Andrew Peterson ${ }^{(c)}$, Thomas Sattler ${ }^{(d)}$

(a) London School of Economics and Political Science

(b) Hertie School, Berlin

(c) University of Poitiers

(d) University of Geneva

Forthcoming in the Socio-Economic Review

\begin{abstract}
The economic imbalances that characterize the world economy have unequally distributed costs and benefits. That raises the question how countries could run long-term external surpluses and deficits without significant opposition against the policies that generate them. We show that political discourse helps to secure public support for these policies and the resulting economic outcomes. First, a content analysis of 32,000 newspaper articles finds that the dominant interpretations of current account balances in Australia and Germany concur with very distinct perspectives: external surpluses are seen as evidence of competitiveness in Germany, while external deficits are interpreted as evidence of attractiveness for investments in Australia. Second, survey experiments in both countries suggest that exposure to these diverging interpretations has a causal effect on citizens' support for their country's economic strategy. Political discourse, thus, is crucial to provide the societal foundation of national growth strategies.
\end{abstract}

Keywords: current account; growth; competitiveness; financial flows; voter attitudes

JEL classifications: F5 International Relations, National Security, and International Political Economy; F1 Trade; F3 International Finance

${ }^{1}$ The authors acknowledge financial support from the Swiss National Science Foundation, grant no. 165480. 


\section{Introduction}

Countries exploit the opportunities stemming from economic openness in very different ways (e.g. Baccaro and Pontusson, 2016; Baccaro and Benassi, 2017; Blyth and Matthijs, 2017). Some countries, such as Germany and Japan, strongly focus on the opportunities from international trade and aim at generating growth by maximizing exports. Others, such as the UK or Australia, rely more heavily on international capital inflows to boost growth by financing domestic consumption and investment. As a result, the external economic balance has been identified as a critical aspect of a country's growth strategy in an open world economy (Baccaro and Pontusson, 2016, esp. pp. 183 and 191-192). More broadly, the global macroeconomy is important to understand the workings of domestic macroeconomic regimes (Blyth and Matthijs, 2017). Export-driven economies have run large external surpluses, while investment-driven economies have run sizable deficits for most of the post-Bretton Woods period. Together, they have repeatedly created a need for domestic and international economic adjustment with adverse effects on international cooperation. ${ }^{i}$

The different growth strategies do not only have the potential to cause international economic conflict; they can also bring disadvantages for the domestic population. Economies with large external deficits are often vulnerable to sudden stops in financing, as the Euro Area crisis has shown (e.g. De Grauwe, 2011; Regan, 2017; Walter, Ray and Redeker, 2020), or experience negative effects on labor markets in areas that house import-competing industries (e.g. Autor, Dorn and Hanson, 2013; Cerrato, Ferrara and Ruggieri, 2018). In perennial surplus countries, wages and domestic investment are chronically low, which has a negative impact on large parts of the population (Jones, 2009).

This paper, therefore, asks how some countries could sustain their growth strategies and run such persistent external imbalances without major domestic opposition against the policies that generate them. The existing literature gives a partial answer to this question. It identifies wage bargaining institutions as a main determinant of the long-term external balance (Hall and Soskice, 2001; Hancké, 2013; Johnston, Hancké and Pant, 2014; Johnston, 2016; Manger and Sattler, 2020), which points to an important part of the mechanism. But it does not explain why this institutional setup receives broader societal support even though it is by no means obvious that a majority of the population benefits from it. In Germany, for 
instance, the exemplar of an export-driven surplus economy, only about a quarter of all employment is linked to exports (Bundesministerium für Wirtschaft und Energie, 2019). Nonetheless, German voters and interest groups consistently support policies that generate external surpluses, such as low-deficit policies (Redeker and Walter, 2020; Hübscher, Sattler and Truchlewski, 2021). It remains unclear why a large majority of the population tolerates a large external surplus that deprives them of higher wages and consumption opportunities. After all, there are plenty political levers that could reduce imbalances. ${ }^{\text {ii }}$ The toleration of a long-run imbalance, thus, is a political decision that requires a political explanation.

Our analysis shows that political discourse is a crucial determinant of citizens' support for policies that produce external imbalances. Building on discursive institutionalism (e.g., Schmidt 2008; Schmidt 2010), we define political discourse as the process by which policy ideas are constructed and conveyed to the public by political actors. We conceive of political actors in a broad manner, with our analysis considering a wide range of groups, encompassing the media, politicians, technocrats and experts.

We focus on the effects of political discourse on citizens' policy preferences and argue that imbalances can be interpreted in two ways: either through a trade logic that highlights competitiveness, or a financial logic that emphasizes investment and savings. The two perspectives focus on very distinct economic mechanisms and are consistent with different sets of policies, or 'growth models.' These interpretations, then, affect how voters in a country think about economic policies and the resulting outcomes. Citizens who are primarily exposed to the competitiveness perspective are more likely to accept 'belttightening' and austerity policies that lead to current account surpluses. Citizens who are exposed to the investment perspective are less likely to support austerity, but favor 'loosening' policies that can lead to current account deficits.

The empirical analysis of Germany and Australia, two countries that represent polar opposites when it comes to their external economic balance, confirms these conjectures. We proceed in two steps: first, we examine how the dominant interpretations of the current account in the political discourse vary between the two countries. Then, we test if discourse has a causal effect on public opinion. 
For the first step, we assess citizens' exposure to different forms of discourse about the current account using a structural topic model analysis of 32,010 German and Australian newspaper articles. We find that the interpretations of the current account presented by the media differ fundamentally across countries. In Australian newspapers, reporting on the current account is more likely to mention investment and savings than competitiveness and productivity. The opposite is true for German newspapers. In the Online Appendix, we validate these results in a variety of ways: first, we present evidence from a qualitative examination of media reports on the current account; second, we employ a dictionary-based approach to confirm the results of the topic model; third, we perform a structural topic model analysis of the speeches of the Reserve Bank of Australia and the Deutsche Bundesbank to show that newspaper reports in fact proxy the dominant interpretations among key policymakers in Australia and Germany. In sum, we provide a big picture of the differences in discourse about macroeconomic imbalances in the two countries.

For the second step, we build on studies about the effects of framing on attitudes towards economic policy (e.g., Ardanaz, Murillo, and Pinto 2013; Harell, Soroka, and Iyengar 2016; Barnes and Hicks 2018) and make use of a survey experiment that tests how people react to a change in the discourse about the current account. In the experiment, we randomly expose respondents to the trade-competitiveness perspective and the savinginvestment perspective. This ensures that we properly identify the causal effect of discourse on attitudes, and not the other way around. The results suggest that citizens' opinions are in fact responsive to the different narratives. The two perspectives influence citizens' approval of a proposed policy package that would reduce the external imbalance. Popular support for policies undergirding external balances is thus susceptible to the economic ideas that are conveyed by different forms of discourse around the current account balance.

To our knowledge, this paper is the first to focus on the effect of discourse on public support for diverging growth strategies and external imbalances. The political economy literature has long highlighted the influence of ideas and discourse on policymaking and institutional change (McNamara, 1999; Blyth, 2002; Schmidt, 2002), and their importance in stabilizing dominant social groups (Amable and Palombarini 2009). Ideas and discourse are notoriously difficult to measure, but recent research has made several advancements in this direction and provided increasing evidence of their influence on economic policy (Chwieroth, 2007; Helgadóttir, 2016; Ferrara, 2020). Our study confirms this by showing how political 
discourse affects the policy preferences of the mass public. In this way, discourse helps to secure societal support for institutional arrangements that embody diverging economic strategies.

\section{Two Perspectives on External Imbalances}

We differentiate between two main perspectives on the current account balance: the trade-competitiveness and the saving-investment perspective. From the first perspective, the current account position is defined as exports minus imports plus net income from abroad. A country will run a surplus when it sells more goods and services than it buys, which implies an important role for international competitiveness. From the second perspective, the position is defined as the difference between domestic savings and investment. A country will run a surplus when there is less domestic investment than there are domestic savings available, which implies an important role for capital flows.

Both perspectives are equally valid. In fact, both measure the same thing and will, per definition, yield the same result. However, since they emphasize different driving forces behind current account dynamics, they guide our thinking in different directions. In other words, "the way we talk about identities and our models can inadvertently shape the inferences we draw from them" (Borio, 2016, p. 2). The two perspectives yield diverging 'policy targets', which are consistent with different 'growth models', as comparative political economy research recently highlighted (Blyth and Matthijs, 2017; Baccaro and Pontusson, 2016). The current account, thus, represents the international dimension of a particular growth model as it is the entity that links the domestic to the international economy.

\subsection{The Trade-Competitiveness Perspective}

The trade-competitiveness perspective played a major role in the history of international political economy, especially for the mercantilism-liberalism debate of the 17th and 18th century (Mun, 1986 [1664]; Smith, 2003 [1776]; Viner, 1948). ${ }^{\text {iii }}$ In short, mercantilists recommended that countries run an external surplus by exporting more than they import to increase a country's power. Although the modern version of this perspective 
highlights the role of jobs and growth rather than power, its recommendations are remarkably similar. Research in the 'neo-mercantilist' tradition suggests that export-promoting strategies, such as exchange-rate undervaluation, promote growth (Rodrik, 2009) and secure domestic jobs (Krugman, 2016).

Versions of the mercantilist view have recently reappeared in interpretations of global imbalances and the Euro Area crisis suggesting that the export-promoting strategy of surplus countries exploits deficit countries. Some assert that Germany consciously undercut the wages of other Euro Area members, hence, robbing them of significant market shares in regional and global trade (Flassbeck and Lapavitsas, 2013, p. 14). Other claim that a surplus is desirable and criticize the Euro Area's deficit countries for their failure to follow the German example (Sinn, 2014). This interpretive framework points to persistent current

account deficits in peripheral countries as the root cause of the crisis and appears to be largely inspired by neo-mercantilist ideas underpinning Germany's growth strategy.

From a less normative point of view, scholars in the field of comparative political economy argue that trade plays a decisive role in shaping current account imbalances and stress the role of institutions in managing wage growth and maintaining competitiveness (Hancké, 2013; Johnston, Hancké and Pant, 2014; Johnston 2016; Manger and Sattler, 2020). Specifically, coordinated wage bargaining systems in combination with the broader institutional framework facilitate wage restraint and limit inflationary pressures (Hall and Franzese, 1998), which helps export-oriented industries to compete internationally. This leads to a strong tendency towards current account surpluses. More broadly, countries that follow different growth models can either rely more on domestic consumption or more on exports, with diverging effects on the current account.

\subsection{The Saving-Investment Perspective}

In contrast, the saving-investment perspective discounts trade flows and highlights international financial flows (Obstfeld and Rogoff, 1996). Already in the 18th century, the mercantilist focus on exports was criticized on the grounds that it was neither desirable nor possible to run a surplus and accumulate precious metals forever (Hume, 1752). More recently, scholars have argued that "forward-looking households and firms ... will generate current-account balances consistent with efficient resource allocation" (Obstfeld, 2012, p. 14) 
and that a current account deficit may be the desirable consequence of real capital movements (Pitchford, 1989, p. 8). Therefore, the perspective provides little rationale for actively steering the current account, be it directly via government intervention or via institutions that support surpluses.

Like its counterpart, the saving-investment perspective plays a prominent role in the interpretation of global imbalances and the Euro Area crisis. Some scholars consider that policymakers' overwhelming focus on restoring competitiveness via wage adjustment was misplaced and priority should have been given to stabilizing the financial system instead (Jones, 2011, 2015, 2016). In the case of the US, former Federal Reserve chairman Ben Bernanke claimed that the "trade balance is the tail of the dog; for the most part, it has been passively determined" (Bernanke, 2005). Such arguments do not only have important policy implications for governments, but also for the more normative question whether or not an external surplus or deficit is desirable or a problem in the first place.

Table 1: Two Perspectives on the Current Account

\begin{tabular}{lll}
\hline & Trade / Competitiveness & Investment / Savings \\
\hline Drivers & $\begin{array}{l}\text { Trade, dependent on } \\
\text { competitiveness and wages }\end{array}$ & $\begin{array}{l}\text { Financial flows, triggered by } \\
\text { investment and savings decisions }\end{array}$ \\
Growth driver & Growth through exports & Growth through investment \\
\hline
\end{tabular}

This is not to say that one would never worry about long-term external imbalances from the saving-investment view. However, even those who see imbalances as useful indicators of potential financial crises point out the risks of both surpluses and deficits (Obstfeld, 2012). Others go even further by claiming that the importance of the current account is overstated, and that more attention should be paid to financial flows instead (Borio, 2016). In the policy debate, the investment perspective is widespread among international organizations. Despite the differences between their procedures of macroeconomic surveillance (Moschella, 2014), both the European Commission and the International Monetary Fund have recently recommended that Germany act against its large current account surplus by increasing investment (European Commission, 2016; International Monetary Fund, 2016). Table 1 summarizes the two perspectives and their implications. 


\section{Building Popular Support for an Economic Strategy: The Role of Political Discourse}

How do the different perspectives matter $?^{\text {iv }}$ Our analysis suggests that they affect citizens' attitudes towards economic policies via political discourse. We define political discourse as the process by which political actors construct policy ideas and convey them to the public. By employing the term political actors, we do not just refer to politicians, but virtually any group that communicates to the public and potentially shapes its preferences: this includes the media, non-elected policymakers and experts.

We adopt a discursive institutionalist approach and see discourse as a more versatile and overarching concept than ideas: the term "discourse" may be used to indicate the interactive processes by which ideas are conveyed as well as their substantive ideational content (Schmidt 2008). Discursive institutionalism conceptualizes discourse along two different dimensions: ideas are created, elaborated and justified with "coordinative" discourse, while "communicative" discourse denotes the process of deliberation and communication of ideas to the public (Schmidt 2010).

Coordinative discourse is performed by political actors involved in the formulation and construction of policy ideas. These actors interact with each other to shape the common understanding of policy problems. Coordinative discourse is typically performed by coalitions of activists, e.g., "advocacy networks" (Keck \& Sikkink 1998), or communities of experts organized on the basis of shared cognitive and normative beliefs, e.g., "epistemic communities" (Haas 1992). But coordinative discourse equally involves elected officials and policymakers discussing with each other, often behind closed doors, as well as representatives of labor unions, employers' associations and sectoral interests. All these actors participate in interactive processes aimed at making sense of complex social phenomena, thereby producing cognitive and normative policy ideas that define the boundaries of feasible and desirable policy action.

Communicative discourse regards the action of bringing ideas to the forefront and conveying them to the public for deliberation and legitimation. The actors typically involved in this process are political leaders attempting to persuade the public to get (re-)elected, as 
well as technocrats sharing their views and explaining their decisions to ensure accountability and gain legitimacy with the public. Yet communicative discourse encompasses other political actors as well, including the media and experts (Schmidt 2008: 310). The communicative discourse of this wide range of political actors feeds into the public debate, which then affects citizen perceptions and evaluations of economic policies.

Thus, political discourse does not only have important implications for the construction of policy actors' consensus over economic policy in coordinative arenas (Hay and Rosamond, 2002). By means of its communicative function, political discourse also helps to promote a wider societal consensus about the national interest among those who do not directly benefit from imbalances. In this paper, we focus on this latter dimension of political discourse. We acknowledge that different ideas have different origins and may be constructed in different ways, but the analysis of the ideational roots of different discourses on the current account and the way they are constructed in coordinative arenas go beyond the scope of this paper. Rather than focusing on the origins of ideas about current account imbalances, we choose to assess the implications of the ideas and interpretations conveyed by political discourse in this policy domain. We provide an empirical assessment of how political discourse about the current account affects the policy preferences of the mass public.

The current account plays an important role in the political discourse because it is widely accepted as a key indicator of economic performance (Financial Times, 1988; Lee, 2009). At the same time, interpretations of current account deficits and surpluses differ widely. Like many key economic terms, the meaning of a current account surplus or deficit is "contingent on the particular cultural frame and social setting" (Matthijs and McNamara, 2015, p. 225). What a current account surplus or deficit says about the state of the economy and whether it should be a policy target that requires action by the government is open to interpretation (Blyth and Matthijs, 2017). The competing interpretations of global imbalances and the Euro Area crisis discussed in the previous section illustrate this point.

The discourse regarding the "optimal" current account balance varies by country. Political actors rely on policy ideas to define what is in the general interest and to separate legitimate from illegitimate political demands (Amable and Palombarini, 2009). The discourse on current accounts, therefore, is instrumental to generate broad societal support for a particular growth strategy (Baccaro and Pontusson, 2016). For instance, the 
competitiveness perspective motivates the reliance on foreign demand to drive long-term development in an export-led growth model. In this way, discourse may secure support for a particular growth model among citizens by defining what constitutes a viable policy solution for their country (McNamara, 1999; Blyth, 2002; Schmidt, 2002; Best, 2004; Matthijs and McNamara, 2015).

Discursive processes are, of course, not the only possible explanations for policies that maintain imbalances. Material considerations and institutional factors can play an important role, given that external adjustment has distributive consequences that affect welfare across groups in the population (e.g. Frieden, 1991; Walter, 2013; Ferrara and Sattler, 2018). For instance, restrained wage growth and internal devaluation strategies ensure the export competitiveness of manufacturing industries. These macroeconomic strategies are favored by coordinated wage bargaining systems, as in the case of Germany, where manufacturing industries typically constitute an important share of the national economy (Manger and Sattler 2020). Thus, the prevalence of competitiveness narratives in these countries may be seen as epiphenomenal to the presence of strong sectoral interests that benefit from them. However, even in an archetypical surplus country like Germany, only around a quarter of all employment is directly or indirectly linked to exports (Bundesministerium für Wirtschaft und Energie, 2019; IWD, 2020). For most Germans, prioritizing international competitiveness over consumption or investment does not yield immediate material benefits. Nonetheless, German voters and interest groups consistently support policies that generate external surpluses, such as fiscal restraint and low-deficit policies (Redeker and Walter, 2020; Hübscher, Sattler and Truchlewski, 2021).

Given the complexity of external economic relations, it is plausible that citizens' attitudes in fact are influenced by the political discourse in their country. Most citizens have only a vague idea about the usefulness of different growth strategies and their effects on the external economic balance of their country. Few people would doubt that higher wages or lower unemployment rates are good for them because the effects are immediate and direct. But alternative policies aimed at achieving economic growth, and their expected effects on specific actors and on the economy as a whole, are a much more complex issue. ${ }^{v}$ In such a situation, a predominant discourse helps people define their interest. 
To be sure, when arguing that political discourse influences citizens' policy preferences, we do not claim that the effect of ideas and discourse is causally independent from that of structural realities and institutional factors. We cannot exclude that political discourse affects public opinion in a way that is conditional upon the material interests and institutional setting of a given society. For instance, it may be that the competitiveness perspective resonates more with German citizens for reasons that are related to the structure of the German domestic economy, its sectoral interests and wage bargaining institutions. However, the assessment of the influence of political discourse on policy preferences, be it conditional or independent, remains important to understand the foundations of different countries' growth models and is currently a blind spot in the literature.

The news media play an important role for the transmission of the substantive ideational content of political actors' discourse to the public and constitute the primary source of exposure for citizens to the policy ideas of politicians, technocrats and experts. Media reporting significantly influences the economic views of the public (Barnes and Hicks, 2018; Boef and Kellstedt, 2004). Its effect on voters can even be greater than that of actual macroeconomic data (Kayser and Leininger, 2015). Furthermore, the importance of framing effects is well-established (Chong and Druckman, 2007). News play an especially important role for attitude formation when individuals feel an increased need for orientation because an issue is relevant, yet ambiguous or hard to understand (McCombs and Reynolds, 2009; Barnes and Hicks, 2018). We can therefore expect that the coverage of the different perspectives on the current account balance will shape public opinion about optimal economic policy. ${ }^{\mathrm{vi}}$

The implication is that, in a country where the competitiveness view dominates the discourse about the current account, it is easier for political actors to justify "belt-tightening" policies that can be politically risky (Hübscher et al. 2015; Hübscher 2018; Hübscher et al. 2020), but which are important to achieve competitiveness and higher exports and, hence, an external surplus (Baccaro and Benassi, 2017; Haffert, 2019). Citizens who are continually exposed to this perspective are more inclined to accept these policies because they believe that they are in their own interest as well as that of the country. In contrast, in a country where the investment perspective dominates, we can expect citizens to tolerate policies that generate an external deficit because it can be interpreted as an indicator of high investment levels. Painful government interventions to reduce the deficit are harder to justify in such an 
environment because the investment perspective stresses the ability of private actors to determine the optimal external balance. The empirically observable implications of this argument are as follows:

HYPOTHESIS 1: (a) In deficit countries, political discourse highlights the investment perspective more than in surplus countries. (b) In surplus countries, political discourse highlights the competitiveness perspective more than in deficit countries.

HypOTHESIS 2: (a) Citizens who are exposed to political discourse highlighting the competitiveness perspective accept contractionary policies that are aimed at reducing the current account deficit more than people who are not exposed to it. (b) Citizens who are exposed to political discourse highlighting the investment perspective accept expansionary policies that are aimed at reducing the current account surplus more than people who are not exposed to it.

\section{Empirical Analysis}

\subsection{Case Selection}

As Figure Error! Reference source not found.1 shows, several advanced economies have experienced sizable imbalances over the last 40 years. ${ }^{\text {vii }}$ In addition, the standard deviations in Figure 1 indicate that the current accounts for many countries do not cycle between deficits and surpluses, but remain either in deficit or surplus for most years

For our analysis, we choose Australia and Germany because the two countries experienced fundamental differences in the long-term external balance as Figure 1 shows. Australia has run current account deficits of 3 percent of GDP or more for the better part of the last 50 years but is nonetheless seen as a particularly successful economic model (The Economist, 2016). Among the notorious deficit countries listed in Figure 1 it is clearly the most interesting case. Spain's high average deficit is heavily influenced by the huge deficits after joining the euro, while it did not strongly lean towards deficits before. The US also runs a large deficit, but this is often attributed to the US dollar's status as reserve currency of the world (Gourinchas and Rey, 2005; Helleiner and Kirshner, 2009). 


\section{Figure 1: Average current account balances (\% of GDP) of large advanced economies,}

1977-2018

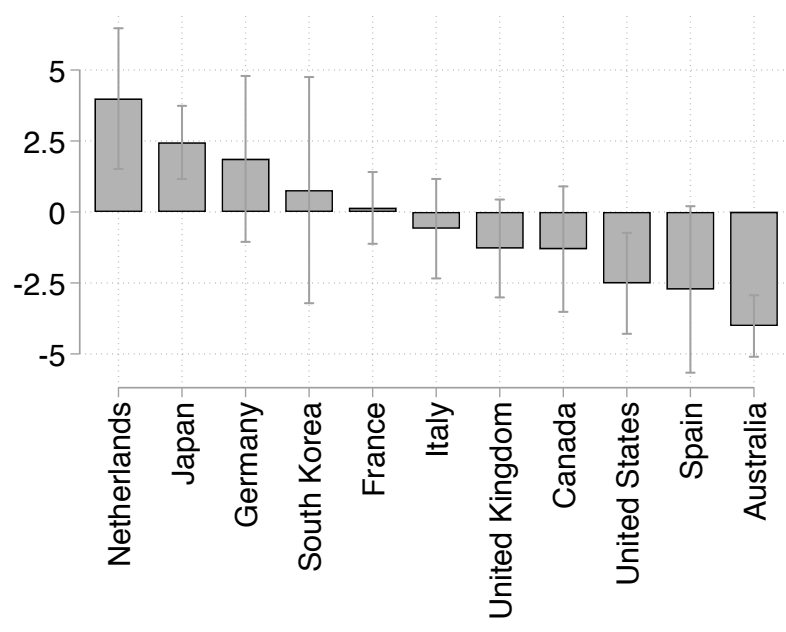

Among the surplus countries, Germany is a particularly intriguing case. The country has always run surpluses since records about current account balances began, except in the late 1970s after the oil shocks and in the 1990s after German unification. The country's response to these shocks underlines Germany's role as a prototype surplus country. Even the enormous costs of reunification pushed Germany into (moderate) deficit only for a decade because German society made massive efforts to move the current account back into surplus. Since then, Germany has been running ever-larger surpluses. While membership in Europe's economic and monetary union arguably contributed to this development, disaggregating the data by counterparty shows that in most years, the imbalances were primarily accumulated vis-à-vis the world outside the euro area (Micossi, D'Onofrio, and Peirce, 2018, 1; Kollmann et al., 2014, 23). Similarly, Germany already ran persistent surpluses already in the late 1960s, which contributed to the destabilization of the Bretton Woods system, in the 1970s after the breakdown of the Bretton Woods system, and throughout the 1980s, long before the start of the Euro Area. It is plausible that without unification Germany's average surplus measured as a percentage of GDP would exceed the surpluses of Japan or the Netherlands. More importantly, German surpluses are enormous in absolute terms. As a result, the imbalance has a considerable impact on other countries and the world economy as a whole. In nine of the last ten years, Germany had the largest current account surplus among advanced economies, as measured in current US dollars. In 2019, the surplus stood at 273 billion US dollars, one and a half times larger than that of Japan and three times larger than 
that of the Netherlands. German macroeconomic strategy has therefore spurred a significant amount of debate (e.g., Bonatti and Fracasso, 2013; Armingeon and Baccaro, 2015; Bernanke, 2015; den Haan et al., 2016; Dieter, 2018). Our analysis connects to these previous studies.

Figure 2: Current accounts of Australia and Germany (percent of GDP)

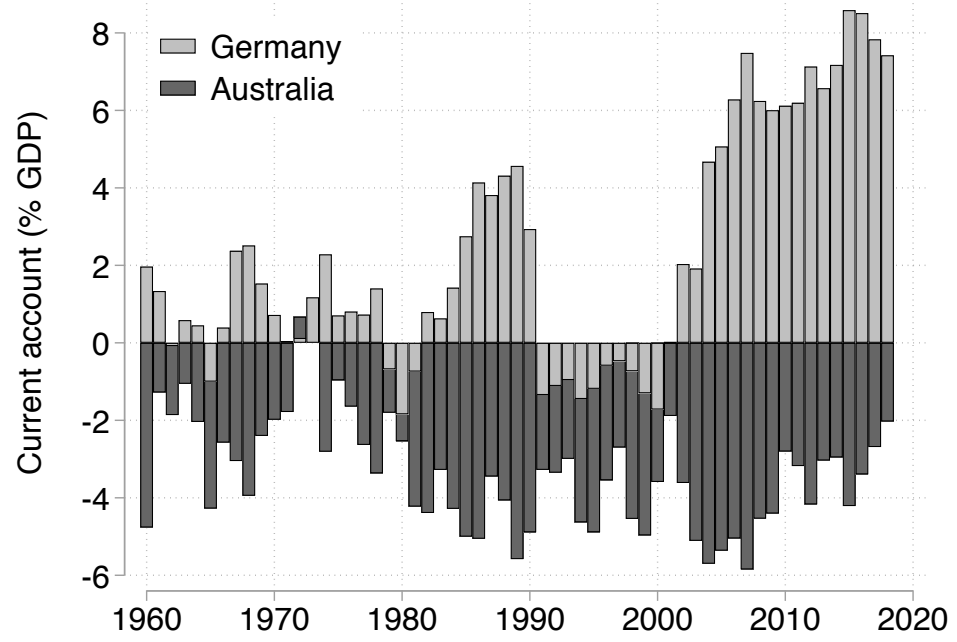

\subsection{Research Strategy}

Following our theoretical discussion and hypotheses, our analysis proceeds in two parts. The first part, which we present in section 5, examines whether the political discourse on the current account differs between Australia and Germany. We focus on both media reporting and the public communication of influential policymakers. Hypothesis 1 would predict that the competitiveness perspective is more prevalent in Germany and the investment perspective is more common in Australia. The second part, which we present in section 6, conducts a survey experiment in both countries. We study the effect of the two different interpretations of the current account on citizens and how their attitudes towards economic policies vary with diverging exposure to these theoretical perspectives. Hypothesis 2 would predict that exposure to the competitiveness perspective increases support for policies that move the current account towards a surplus, while exposure to the investment perspective increases support for policies that move the current account towards a deficit. 
For our analysis of differences in political discourse, we proceed as follows. We start from assessing differences in media reporting. For newspaper reports, we choose quality publications that provide variation across the ideological spectrum and are sold nationwide. For each country, we include a left-leaning, a conservative, and a business newspaper. For Australia, we retrieve articles from the Sydney Morning Herald (left-leaning), The Australian (conservative), and the Australian Financial Review (business). They represent three out of four traditional Australian quality newspapers and account for about $70 \%$ of sales in that sector. ${ }^{\text {viii }}$ For Germany, we collect articles from the Süddeutsche Zeitung (left-leaning), Die Welt (conservative), and the Handelsblatt (business). Frankfurter Allgemeine Zeitung, an important conservative newspaper, could not be included because of cost restrictions. However, the media in our sample account for two thirds of nationwide quality daily sales and each of them is among the top five. In all cases, we adopted the same search procedure and selected all the articles with reference to the respective country and the terms "current account balance" or "trade balance" in the main text. Data availability differed by newspaper source. ${ }^{\text {ix }}$ Table 2 provides more detailed information on the composition of our text corpus.

Table 2: Composition of Australian and German Corpora of Newspaper Articles

\begin{tabular}{lcc}
\hline & No $^{\circ}$ Articles & Starting Year \\
\hline Australia & 17194 & 1986 \\
Germany & 14816 & 1986 \\
\hline The Australian & 3360 & 1995 \\
Sydney Morning Herald & 5083 & 1986 \\
Australian Financial Review & 8751 & 1987 \\
\hline Die Welt & 995 & 1999 \\
Süddeutsche Zeitung & 1440 & 1995 \\
Handelsblatt & 12381 & 1986 \\
\hline
\end{tabular}

The newspaper articles are examined with a structural topic model (STM), which allows us to identify the key topics related to competitiveness and investment that appear in newspaper articles mentioning the current account (Roberts, Stewart \& Tingley, 2019). To validate these results, in the Online Appendix, we provide a qualitative analysis of media reports and employ a dictionary-based approach, for which we identify key terms associated 
with the two perspectives on the current account based on our theory (e.g., Fan 1988, p. 4450; Burden and Sanberg 2003; Young and Soroka 2012). Furthermore, we test whether the discourse of influential policymakers is really consistent with media reporting, which constitutes an underlying assumption of our theoretical framework. In the Online Appendix, we use STM to analyze portions of speeches about the current account of the Reserve Bank of Australia and the Deutsche Bundesbank. Jointly, these approaches paint a detailed picture of the role played by the two perspectives in the Australian and German debates about current account balances.

The subsequent survey experiment then directly builds on the text analysis by examining how the perspectives on the current account transported by the dominant discourse affect popular attitudes. A key question is whether these different interpretations in fact have a meaningful effect on public support for a country's growth strategy and the associated economic policies. The survey experiment allows us to examine whether such a causal effect exists. Our demonstration of framing effects on attitudes towards external imbalances adds to similar findings in the literature on government expenditure (Jacoby 2000), trade preferences (Ardanaz, Murillo, and Pinto 2013), redistribution (Harell, Soroka, and Iyengar 2016) and attitudes towards austerity (Barnes and Hicks 2018).

In the survey, respondents in both countries are reminded how the current account balance in their respective country has developed in the past years. In other words, Australians are confronted with a deficit scenario, while Germans are confronted with a surplus scenario. We then provide respondents with different interpretations of the situation that their country faces. Each interpretation matches one of the two theoretical perspectives attested in the newspaper analysis. A German respondent, therefore, would see an expert statement that interprets the German surplus either through the competitiveness or the investment perspective. An Australian respondent would see an expert statement that interprets the Australian deficit either through the competitiveness or the investment perspective. We also include a control group that does not see any of the two interpretations. We simultaneously fielded the surveys to ca. 1,000 respondents in each country in August 2018 .

After confronting respondents with these interpretations, we ask all of them to what extent they approve of a set of policies that aim at altering the current account balance. In 
Australia, this is a set of "belt-tightening" policies that aim at reducing the current account deficit. In Germany, this is a "loosening" of economic policies that aim at reducing the surplus. Since respondents are randomly assigned to a particular interpretation or the control group, the differences in their responses represent the causal effect of the different interpretations on respondents' approval of the suggested policies.

\section{Text Analysis}

We analyze the media coverage of current account balances using three methods, each with its own advantages and drawbacks. Reassuringly, they reach the same conclusions. First, we employ a structural topic model (STM) to identify discourses through the tendencies to employ any of a number of possible words. We make use of this technique to study the two corpora of newspaper articles. In doing so, we build on previous studies that have effectively used STM to model the framing of international newspapers (Roberts, Tingley and Airoldi, 2016; Barnes and Hicks 2018).

In the Online Appendix, we validate the results of this approach. First, we conduct a qualitative examination of relevant articles in our text corpora, providing examples of how the two perspectives on the current account balance are represented in Australian and German newspapers. Second, we confirm the results of the STM analysis by applying a simpler and easier-to-reproduce dictionary-based approach. Third, in line with recent studies using topic modeling to analyze the speeches given by central bankers (Moschella and Pinto 2018; Diessner and Lisi 2019; Cross and Greene 2019), we use STM to shed light on Australian and German central bankers' communication on current account imbalances. The results show that the Deutsche Bundesbank's discourse around the current account differs substantially from that of the Reserve Bank of Australia, with the former adhering to the competitiveness view and the latter promoting the investment perspective.

The joint application of this set of methods ensures that the different approaches validate each other in showing that there are significant differences between Australia and Germany in the political discourse around current account balances. 


\subsection{Structural Topic Model}

In this section, we use a structural topic model (STM) to identify the presence of word clusters in newspaper articles that are consistent with our theoretical framework and estimate their relationship to document metadata. Topic models are increasingly used to systematically investigate and interpret discourse in large collections of texts (Jacobs and Tschötschel 2019). As explained in detail by Roberts, Stewart and Tingley, STM allows researchers to discover topics in a text corpus and conduct hypothesis testing about the relationship between topics and document-level covariates (Roberts, Stewart and Tingley, 2019). Here, we focus on estimating the proportion of text devoted to topics of interest both across newspapers and over time. STM has the advantage that it can isolate word clusters that are related to the competitiveness and investment perspectives, and separate them from other, potentially confounding, topics. This ensures a more comprehensive analysis of our text corpus than other methods, such as the dictionary-based approach.

First, we create two text corpora, one for Australian newspaper articles and one for German ones, and convert text into a structured form, using standard text processing approaches. In particular, we lowercase and stem words, remove stopwords and numbers, and reduce the size of the document-frequency-matrix by considering only terms that appear in at least $2 \%$ of the documents to improve estimation efficiency (Proksch and Slapin 2009). Second, for each country, we run models iteratively and choose the number of topics based on interpretability (Chang et al., 2009). In both cases, a model with 50 topics gives us a finegrained view over the issues addressed in the Australian and German media, and yields topics that are theoretically meaningful. In Section A.1 of the Online Appendix, we justify the selection of the number of topics in greater detail and show that this number constitutes a balanced choice in terms of topic exclusivity and semantic coherence.

In both the Australian and the German case, we can identify three topics that are highly relevant to our research question. In Table 3, we give an overview of such topics. "Highest probability" is a simple measure that indicates which words are the most likely to co-occur in a given word cluster. The FREX metric indicates "exclusive" words - namely, those that are highly likely in one topic and unlikely in other topics (Airoldi and Bischof, 2016). 
Table 3: Top Words for Australian and German Topics

\begin{tabular}{ll}
\hline & \multicolumn{1}{c}{ Australia } \\
\hline Industrial Investment & invest, busi, small, survey, capit, plan, firm \\
Highest Probability: & busi, invest, survey, small, featur, firm, plan \\
Exclusivity (FREX): & market, investor, fund, bond, year, global, equiti \\
\hline Financial Investment & investor, equiti, bond, portfolio, asset, fund \\
Highest Probability: & \\
Exclusivity (FREX): & reform, industri, competit, polici, australia, market, product \\
\hline Competitiveness & reform, competit, tariff, protect, effici, micro-econom, structure \\
Highest Probability: & $\quad$ Germany \\
\hline Exclusivity (FREX): & \\
\hline
\end{tabular}

\section{Industrial Competitiveness}

Highest Probability:

unternehmen, industri, produkt, jahren, markt, entwicklung, investitionen [company, industr, produc, years, market, development, investment]

Exclusivity (FREX):

wettbewerb, bewertung, standort, bereich, produkt, unternehmen, schweden [competition, valuation, location, sector, product, company, sweden]

\begin{tabular}{ll} 
International Competitiveness & \\
Highest Probability: & $\begin{array}{l}\text { deutschland, frankreich, euro, euro-zon, wettbewerbsfähigkeit, } \\
\text { spanien, mehr [germany, france, euro, euro area, competitiveness, } \\
\text { Spain, more] }\end{array}$ \\
Exclusivity (FREX): & $\begin{array}{l}\text { wettbewerbsfähigkeit, österreich, löhne, spanien, währungsunion, } \\
\text { griechenland, portug [competitiveness, austria, wages, spain, } \\
\text { monetary union, greece, portug] }\end{array}$ \\
\hline Investment & \\
Highest Probability: & $\begin{array}{l}\text { anleg, fond, aktien, invest, investoren, manag, jahr [invest, fund, } \\
\text { stocks, invest, investors, manag, year] }\end{array}$ \\
Exclusivity (FREX): & $\begin{array}{l}\text { fond, invest, anleg, manag, hielten, immobilien, market [fund, } \\
\text { invest, invest, manag, held, real estate, market] }\end{array}$
\end{tabular}

In Australia, the first investment topic expresses an industrial perspective, as the stemmed word "invest" appears in association with the terms "business", "firm", "small" "capital", and "plan". The second Australian investment topic, instead, suggests a mere financial perspective, being defined by the words "investor", "fund", "bond", "global", 
"equity", "portfolio", and "asset". The third Australian topic of interest is the only topic produced by the model that is defined by the word "competitiveness" ("competit" in the stemmed form). This is associated with policy-relevant terms, such as "reform", "polici", "market", "product", and "structur". Therefore, the first two considered Australian word clusters can be easily ascribed to the investment perspective on the current account, while the third one reflects a narrative of the current account that is much more in line with the competitiveness perspective. This interpretation of the discussed topics is also confirmed by text excerpts containing high proportions of these topics, presented in section A.2 of the Appendix.

In Germany, the term "competitiveness" ("wettbewerbsfähigkeit") plays a more prominent role, as it is one of the defining terms in two different word clusters. The first topic sees "competit" ("wettbewerb") in association with business terms, such as "firms", "industry", "development", "market", and "product" ("unternehmen", “industri", "entwicklung", "markt", "produkt"). The word "investment" ("investitionen") also has high probability to appear in this topic, but it is not among the words that are most exclusive to it. We conclude that this is a topic about the competitiveness of domestic firms, and define this topic as one about industrial competitiveness. The second German topic is characterized by the term "competitiveness" in a more international perspective, as it is associated with references to the Euro Area, as well as France, Spain, Greece and Portugal. "Wages" ("löhne") is another defining term of this word cluster, which further indicates that this is a topic about international competitiveness. Finally, we can detect the presence of a topic that can be unambiguously ascribed to investment - most notably, in financial terms - as it is defined by "invest" (both with "anleg" and "invest"), "fund" ("fond"), and "stock" ("aktien"). Thus, we conclude that, for the German topic model, two word clusters are consistent with the competitiveness perspective, while one is more clearly in line with the investment one. Section A.2 in the Online Appendix shows relevant text excerpts from the STM analysis of the German text corpus.

The presence of two investment topics and only one competitiveness topic in Australia, as well as the presence of two competitiveness topics and only one related to investment in Germany, is consistent with our theoretical framework. In addition, we directly test this hypothesis by estimating the expected proportions of these topics over time. 
Figures $3 \mathrm{a}$ and $3 \mathrm{~b}$ present time series estimates showing the evolution of these topics from the late 1980s to 2018 in, respectively, Australia and Germany. Figure 3a clearly shows that the industrial investment topic always played a minor role in Australia. In contrast, the estimated proportion of the competitiveness topic in Australia was relatively more prominent in the late '80s and early '90s. However, discussions about financial investment in reference to the current account have gained increasing importance over time: by the mid-90s they started receiving more attention than issues of competitiveness, and this has consistently remained so until nowadays. It may be no coincidence that this shift happened when the socalled "Pitchford thesis" gained prominence (Belkar, Cockerell and Kent, 2007). This thesis, put forward by the Australian economist John Pitchford, suggests that a current account deficit is not necessarily a problem and can be optimal (Pitchford, 1989). This is the case if rational individuals decide to borrow money from abroad and repay these loans with returns from their investment.

The picture for Germany is the opposite. Figure 3b exhibits a consistent pattern of prevalence of the two competitiveness topics vis-à-vis the financial investment one: with the only exception of the years preceding the Global Financial Crisis, the two topics defined by the term "wettbewerbsfähigkeit" are estimated to always have greater coverage than financial investment. Also, it is important to notice how the German media's view of competitiveness has shifted over time from a more domestic perspective, expressed by the industrial competitiveness topic, to a European one, expressed by the cluster of words ascribed to international competitiveness. Our analysis suggests that the Euro Area crisis has greatly contributed to shaping German sensitivity to competitiveness issues. This is consistent with our expectations on the evolution of German political discourse from the Reunification period to nowadays. 
Figure 3a: Time Series Estimates of Relevant Topics for Australia, 1989-2018

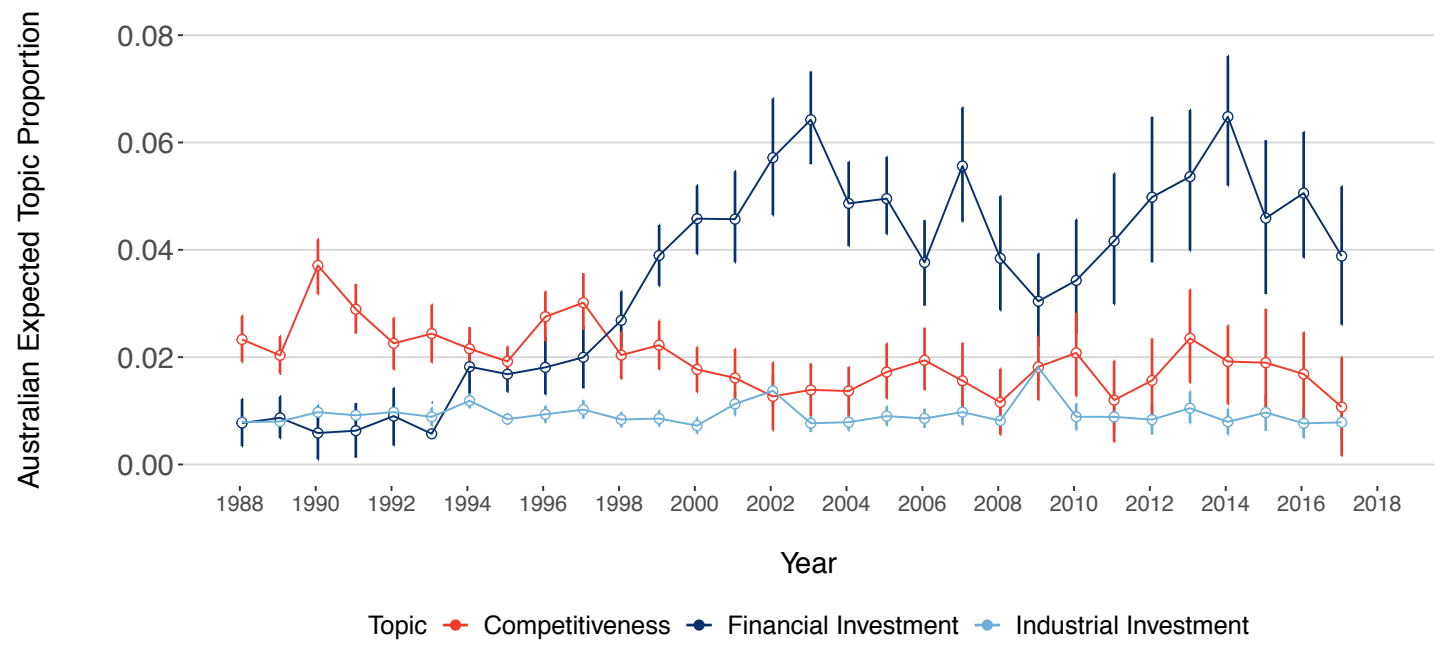

Figure 3b: Time Series Estimates of Relevant Topics for Germany, 1987-2018

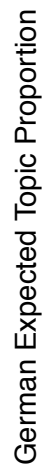

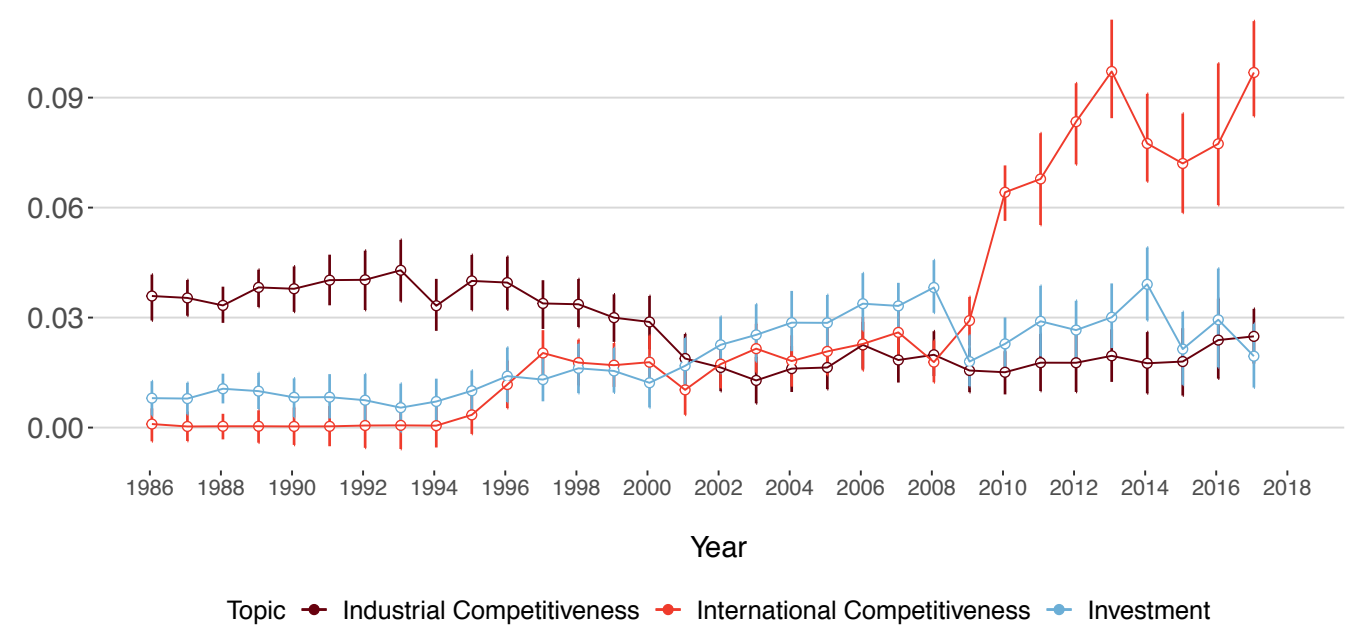

Overall, these results confirm the presence of two different narratives of the current account balance in Australia and Germany. In Australia, the discourse around the current account, here proxied by media reporting, tends to highlight issues of investment more than in Germany. Importantly, financial investment is devoted most attention, which is consistent 
with the investment perspective's emphasis on international financial flows. Conversely, the German media tend to highlight issues of competitiveness in relation to the current account balance more than Australian ones. Hence, the results suggest that the discourse in Germany tends to promote a neo-mercantilist view on the current account.

\subsection{Additional Analyses}

In the Online Appendix, we extend the text analysis to validate the results of STM and provide additional evidence of the divergence of in the political discourse about the current between Australia and Germany. First, we perform a qualitative examination based on a close reading of articles in German and Australian newspapers that report about the current account, covering the period for which all newspapers are available (2000-17). Second, we use a dictionary-based approach to validate the results of this section and show that there are significant differences in the interpretations of the current account in the Australian and German media. Third, we use STM to provide evidence that the discourse of key policymakers in the two countries is similarly biased towards different interpretations of the current account. Analyzing the speeches of the Reserve Bank of Australia and the Deutsche Bundesbank, we provide evidence that Australian central bankers refer extensively to inflows of foreign capital when discussing the current account balance, while they do not talk much about issues of competitiveness. By contrast, German central bankers focus much more on competitiveness and pay little attention to the role of international capital flows.

While the analyses in this section and in the Online Appendix suggest that the Australian and the German perspectives on the current account differ, they do not clarify whether the documented divergence in discourse has a causal effect on individuals' perceptions of macroeconomic issues related to the current account. After all, different types of discourses could be the consequence rather than the cause of how individuals in different countries conceive of the functioning of the economy. By employing an experimental research design, the next section directly addresses this issue. 


\section{Survey Experiment}

We conduct a survey experiment to determine whether the different types of discourse on the current account have a causal impact on citizens' policy preferences. A priori, one could imagine that citizens are simply uninformed about current account imbalances, that their opinions are determined by their cultural and media context, or that they are the result of their personal economic situation, such as whether they work in an export-oriented industry. An experiment allows us to evaluate how exposure to the competitiveness or investment perspectives influences their opinions and isolate this effect from other spurious correlations between these opinions and demographic, social, or economic differences.

In employing this experiment as a test of the theory that political discourse drives external imbalances, we rely on a few key assumptions. First, we presume that the policies adopted are determined in general by public opinion (democratic responsiveness). Secondly, we are assuming that the publics to which policy is responsive are like the participants of our study (external validity), in the sense that they read newspapers or consume other news that contain the investment and competitiveness frames as we identified above in newspapers. Finally, since such experimental effects have been shown to diminish over time, we expect that such exposure is repeated and/or is more common in the lead-up to important policy decisions (on the basis that journalists write about issues relevant to upcoming decisions).

In the experiment, participants are exposed to one of three scenarios. All three scenarios present a basic explanation of current account balances, but (1) the "no framing" condition presents no further interpretation of the imbalance. In the two experimental treatments, participants read additional text that interprets the current account balances either recurring to (2) the competitiveness or (3) the investment perspective. For details of the question wording, see Figure 4, in which for simplicity we present the version for Australia (the German wording is available in the Online Appendix). As Australia regularly runs current account deficits, respondents were told that their country faces a deficit and, following the possible treatment conditions, were asked whether they would support policies to reduce the deficit. The experiment in Germany, which is a surplus country, presented the opposite condition, in which the investment treatment frames the surplus as proof that companies are reluctant to invest in the country, while the competitiveness treatment 
interprets it as the results of high competitiveness and low production costs. In the German survey question, the government proposes a "loosening" of economic policies to reduce the surplus. To minimize the likelihood that responses are driven more by the nature of the communicator rather than by the nature of the message, we decided to talk about the opinion of generic "experts" rather than politicians or other actors in politicized policy domains. This remains consistent with our theoretical framework. As Schmidt (2008: 310) notices, experts are also often involved in processes of communicative discourse.

\section{Figure 4: Wording of Vignette and Survey Question (Australia)}

We will now ask you a few questions about Australia's external economic relations and
the current account. Australia has a persistent current account deficit that is expected to
continue unless policy changes are made. A deficit means that Australia is importing more
goods from abroad than it is exporting to other countries. It also means that more money
is flowing into the country from abroad than there is flowing out to other countries.
Investment-savings treatment
"Experts say that the persistent deficit is a result of high attractiveness of investments in
the Australian economy compared to the level of savings. In particular, money comes in
because foreign firms and investors are deciding to invest in Australia's economy."
Competitiveness treatment
"Experts say that the persistent deficit is a result of the low competitiveness of Australian
producers. In particular, Australian goods and services are expensive compared to goods
and services produced abroad because of the high production costs in Australia."
Policy Response
"The government, together with employers' associations, labor unions, and the central
bank, has several possibilities to affect the current account. Imagine that the Australian
prime minister announces "belt-tightening" measures to reduce the current account deficit.
To what extent do you approve of this announcement?
(1-5 scale: strongly disapprove=1, somewhat disapprove, neither approve nor disapprove,
somewhat approve, strongly approve=5)

While the policy package that respondents evaluated is hypothetical, the subjects were presented scenarios that reflected the situation of the country in which the survey was conducted. That is, in Germany, respondents were informed that the country was running a consistent current account surplus and considered policies that would reduce this surplus, while in Australia they were informed about a deficit and policies to reduce it. One might object that the descriptions should be identical in both countries, such as by assigning participants in both countries to either a deficit or a surplus treatment as well as to the 
treatments suggesting how these imbalances should be interpreted. However, such an approach would simply add an artificial and unrealistic counterfactual, for example asking Germans to believe their country runs deficits, or imagine a world in which it did so, while reducing the power available to analyze the experimental condition that is of interest.

The survey experiment was conducted in Germany and Australia in the summer of 2018 with 2,043 respondents. Respondents came from the survey company Respondi's standing panels. The surveys took place between August 6 and August 26, 2018. Respondents were screened to match the sex and age profile of each country based on census data (for ages 18-65). The survey included questions for other political economy experiments and the order of appearance of the experiments was randomized. The median respondent required 18 minutes to respond to the full survey, so here we drop respondents who took less than five minutes to respond, as it is practically impossible to respond meaningfully to the questions in such a short period.

\subsection{Survey Experiment Results}

First we consider the success of the randomization, not because there is any particular doubt about the survey firms' computer randomization but because of the small attrition created when respondents do not complete the survey or are dropped because they completed the survey in less than five minutes. We present summary statistics and balance tests in the Online Appendix, which confirm that the randomization was effective as expected with respect to these covariates.

To examine the causal effect of the treatments on participants' opinion, we first look at the approval for the policy package to reduce the imbalance, that is to reduce the deficit in Australia and to reduce the surplus in Germany. Figure 5 shows the raw distributions of approval ratings for a package to address the current account balance, by country. We align the responses for the two countries so that a five on the $\mathrm{x}$-axis means strongly approving of a policy package, while a one means rejecting it. The proposed policy package reduces the surplus in the German case, while in Australia it reduces the deficit. First, comparing the overall trends (ignoring treatments), we see that Germans are generally more reluctant to approve a policy that would reduce their surplus than Australians are willing to approve a package that would reduce their deficit. Although a fair amount of Germans responded 
"approve" or "strongly approve" (4 or 5), more than $40 \%$ Australians did so. Second, considering now the different treatment groups (presented in different shades of grey), it is clear from these raw counts that the treatments caused people to move in the expected directions. In Germany, the investment perspective convinced more people to approve a policy package to reduce the surplus, while in Australia the competitiveness treatment caused more people to support a package to reduce their deficit.

Figure 5: Histogram of Policy Approval Responses by Treatment, Country
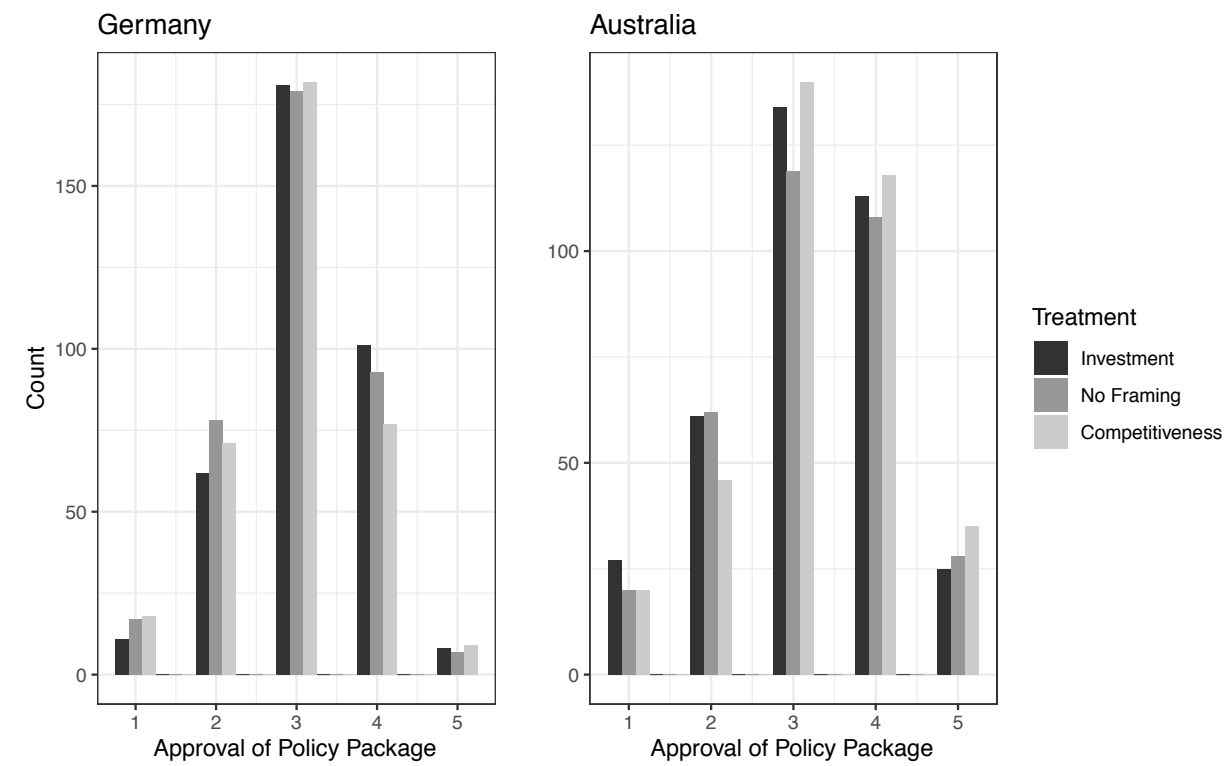

We then perform a quantitative assessment of the causal effect of the two treatments compared to the control group. Figure 6 presents the main results in graphical form. It shows the ordered logit coefficient estimates of the two treatments for four specifications estimated separately for respondents in Germany and Australia. The top (darkest) points of each quartet are estimates from models with no controls; upper middle points are estimates from models controlling for gender and age; lower middle points are estimates from models including gender, age and a measure of the reliance on exports of the industry in which the respondent works ${ }^{\mathrm{x}}$; and bottom (lightest) points are estimates from models including gender, age, reliance on exports, sophistication and political values ${ }^{\mathrm{xi}}$. $95 \%$ confidence intervals are indicated with thin bars, whereas thick bars indicate $90 \%$ intervals. Higher values correspond to greater approval of the policy package aimed at reducing the external imbalance (i.e., "loosening" policy package to reduce the surplus in Germany; "belt-tightening" policy 
package to reduce the deficit in Australia). The complete results from the estimation of all four models are presented in Table 5A in the Online Appendix.

Figure 6: Treatment Effects in Australia and Germany (Ordered Logistic Regressions)

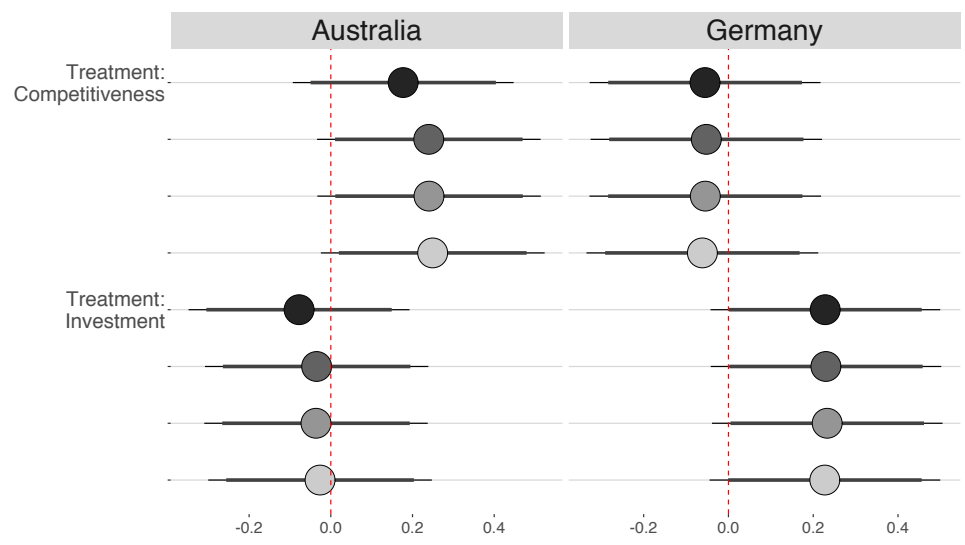

Compared to the "Control" group, who was exposed to no framing, respondents in the "Investment" treatment express greater approval towards policy measures aimed at reducing the current account surplus in Germany. This effect is statistically significant at the $10 \%$ level in three out of four specifications. By contrast, the magnitude of the "Competitiveness" treatment is very small and never significantly different from zero in Germany. The opposite is true for Australia. Here, compared to the "Control" group, respondents in the "Competitiveness" treatment are significantly more likely to be in favor of policy measures aimed at reducing the current account imbalance in three out of four specifications. The causal effect of the "Investment" treatment on policy approval is small in magnitude and never statistically significant. The point estimates are stable across specifications, consistent with the randomization procedure working well across observables. Moreover, the difference between the "Competitiveness" group and the "Investment" group is statistically significant at the $5 \%$ level in all the specifications ${ }^{\mathrm{xii}}$.

In the Online Appendix, we verify the sensitivity of these results to a different model specification. In Figure 3A and Table 6A, we replicate the results presented, respectively, in Figure 6 and Table 5A, using OLS instead of ordered logistic regressions. Using a different model specification does not substantially alter the main picture of results. The main 
difference between OLS and ordered logit is that the "Investment" treatment in Australia is estimated to have slightly lower statistical significance and does not attain the $10 \%$ confidence level. However, the difference between the "Competitiveness" group and the "Investment" group remains statistically significant at the 5\% level in all the specifications in both Germany and Australia, thereby pointing to a significant divergence in the causal effect of the two treatments on respondents' approval of policies aimed at reducing the current account imbalance.

\section{Figure 7: Expected Values of Approval of Policy Package to Reduce Current Account Imbalance}
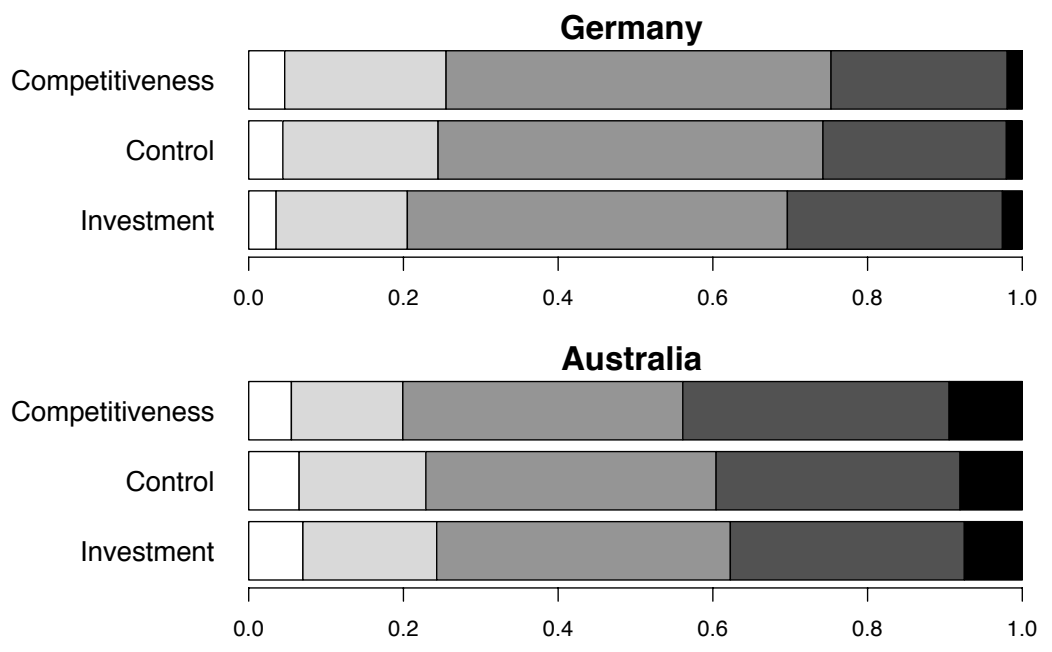

To better quantify the difference between the three groups, Figure 7 illustrates the expected probabilities of each of the five response categories in Germany and Australia, based on the estimates obtained from the first of the four specifications presented in Figure 6. In Germany, the expected probabilities of the five categories are $5 \%, 21 \%, 50 \%, 23 \%$ and $2 \%$ for the "Competitiveness" group, very similar to the "Control" group. However, exposure to discourse informed by the investment perspective makes respondents more supportive towards the reduction of the German current account surplus: the two highest categories of support for a "loosening" policy package receive, respectively, an expected $28 \%$ and $3 \%$ of responses from subjects in the "Investment" group. The opposite is true in Australia, where respondents in the "Competitiveness" group are estimated to "approve" and "strongly 
approve" a "belt-tightening" policy package with, respectively, a 34\% and 9\% probability, while the corresponding probabilities for those in the "Investment" group are 30\% and $7 \%$.

These results provide support for Hypothesis 2, suggesting that the discourse around the current account balance can influence opinion on policies that help determine that balance. Although the exposure to different interpretations is limited in our experiment, the findings provide evidence that citizens' opinions are not fixed but respond to dominant interpretations of the current account. In particular, individuals respond more strongly to the framing that is not dominant in the political discourse in their country, namely the competitiveness view in Australia and the investment perspective in Germany. This result can be seen as a consequence of the systematic divergence of discourse between the two countries that was uncovered in the previous section. Since citizens are consistently and permanently exposed to the competitiveness view in Germany and the investment perspective in Australia, it should come as no surprise that they do not significantly update their attitudes towards the reduction of their country's current account imbalance compared to the respondents in the control group. At the same time, our analysis suggests counterfactually that, if citizens were widely exposed to different interpretations of the current account balance, their opinions on policies to adjust these imbalances would also change. Thus, the findings of this paper challenge the idea that societal support towards macroeconomic imbalances in these two countries is to be taken for granted and could not be reversed if different strategies of communicative discourse around the current account became dominant in countries with external imbalances.

\section{Conclusion}

This paper sheds light on popular support for external imbalances and the policies that generate them by examining the policy ideas conveyed to citizens via political discourse. Our comparative analysis of Australia, a notorious deficit country, and Germany, a notorious surplus country, reveals important differences. Australian newspapers and policy actors tend to discuss the current account balance in the context of capital flows and view the deficit as proof that their country is a highly popular investment destination. By contrast, German newspapers and policy actors discuss the current account predominantly in the context of 
trade. They consider their country's surplus to be an expression of superior competitiveness and successful economic policy.

These differences are compatible with two distinct theoretical perspectives on external balances, which represent the international dimension of different national growth models. The investment perspective stresses the importance of capital flows that are the result of rationally acting firms and households. The competitiveness perspective stresses the role of wages and competitiveness. Our paper presents a systematic analysis of how different forms of discourse about the current account generate popular support for external imbalances and the underlying economic strategies that generate these imbalances. Political debates, e.g. about the imbalances in the Euro Area, have repeatedly pointed to the presence of such distinct theoretical lenses in different countries (Brunnermeier, James and Landau, 2016; Jones, 2016). Our analysis allows us to explore this claim in a larger context, beyond the politicized debates surrounding the Euro Area crisis.

The results show how political discourse helps secure support for diverging national growth strategies and the domestic economic institutions that back these strategies (Hall and Soskice, 2001; Baccaro and Pontusson, 2016; Manger and Sattler, 2020). Although institutional complementarities are important determinants of economic policies, these arrangements must be supported by a broad societal coalition in order to be durable. We show that the presence of distinct types of discourse about the current account balance helps generate societal support for the policies and outcomes that follow from domestic economic institutions. Discourse, therefore, has a stabilizing effect on a country's macroeconomic regime, or growth model. At the same time, this also suggests that growth models are by no means unchangeable. Popular support for a growth model can change over time if the discourse of influential political actors changes, together with underlying policy ideas.

Our findings indicate that resolving international economic imbalances might be as much about communication as it is about economics, and points to the need to better understand the sources and determinants of different types of discourse on the current account. ${ }^{\text {xiii }}$ The experimental results suggest that viewing economic imbalances simply as the result of different policies falls short of a satisfying explanation. Even assuming that such policies are welfare maximizing and optimal given countries' different factor endowments, it is important to understand how they are maintained, given that, as our results show, citizens' 
support for them depends in part on the interpretation they are offered. While beyond the scope of this paper, further research is needed on the question what or who is driving such differences in discourse upstream. One promising approach would be to check whether imbalanced economies with structures that differ from those of Australia and Germany display similar political discourses. In the absence of such studies, our paper makes no claim to generalizability, but rather serves as a starting point that underlines the importance of seeking out more information about these processes. 


\section{References}

Airoldi, E. M. and Bischof, J. M. (2016) 'Improving and Evaluating Topic Models and Other Models of Text', Journal of the American Statistical Association, 111, 1381-1403.

Amable, B. and Palombarini, S. (2009) 'A Neorealist Approach to Institutional Change and the Diversity of Capitalism', Socio-Economic Review, 7, 123-143.

Ardanaz, M., Murillo, M. V. and Pinto, P. M. (2013) 'Sensitivity to Issue Framing on Trade Policy Preferences: Evidence from a Survey Experiment', International Organization, 67, 411-437.

Armingeon, K., and Baccaro, L. (2015) “The Crisis and Germany. The Trading State Unleashed", in Complex Democracy, edited by Volker Schneider and Burkard Eberlein, 165-183, Springer International Publishing.

Autor, D. H., Dorn, D., and Hanson, G. H. (2013) 'The China Syndrome: Local Labor Market Effects of Import Competition in the United States', American Economic Review, 103, 2121-2168.

Baccaro, L. and Benassi, C. (2017). 'Throwing Out the Ballast: Growth Models and the Liberalization of German Industrial Relations', Socio-Economic Review, 15, 85-115.

Baccaro, L. and Pontusson, J. (2016) 'Rethinking Comparative Political Economy: The Growth Model Perspective', Politics \& Society, 44, 75-207.

Baldwin, R. and Giavazzi, F. (2015) The Euro Area Crisis. A Consensus View of the Causes and a Few Possible Remedies, London, Centre for Economic Policy Research.

Barnes, L. and Hicks, T. (2018) 'Making Austerity Popular: The Media and Mass Attitudes Towards Fiscal Policy', American Journal of Political Science, 62, 340-354.

Belkar, R., Cockerell, L. and Kent, C. (2007) Current Account Deficits: The Australian Debate. Reserve Bank of Australia Research Discussion Paper 2007/02, accessed at http://www.rba.gov.au/publications/rdp/2007/pdf/rdp2007-02.pdf on January 10, 2019. 
Bernanke, B. S. (2005) 'The Global Saving Glut and the U.S. Current Account Deficit', accessed at http://www.federalreserve.gov/boarddocs/speeches/2005/200503102/default.htm on January 11, 2019.

Bernanke, B. (2015) “Germany's Trade Surplus is a Problem”, accessed at https://www.brookings.edu/blog/ben-bernanke/2015/04/03/germanys-trade-surplus-is-aproblem/ on 27 March 2020.

Best, J. (2004) 'Hollowing Out Keynesian Norms: How the Search for a Technical Fix Undermined the Bretton Woods Regime', Review of International Studies, 30, 383-404.

Blyth, M. (2002) Great Transformations: Economic Ideas and Institutional Change in the Twentieth Century, Cambridge, Cambridge University Press.

Blyth, M. and Matthijs, M. (2017) 'Black Swans, Lame Ducks, and the Mystery of IPE's Missing Macroeconomy', Review of International Political Economy, 24, $203-231$.

Bonatti, L. and Fracasso A. (2013) 'The German Model and the European Crisis', Journal of Common Market Studies, 51, 1023-39.

Borio, C. (2016) 'On the Centrality of the Current Account in International Economics', Journal of International Money and Finance, 68, 266-274.

Brender, A. and Pisani, F. (2010) Global Imbalances and the Collapse of Globalised Finance, Brussels, Centre for European Policy Studies (CEPS) Paperbacks.

Brunnermeier, M. K., Harold, J. and Landau, J-P. (2016) The Euro and the Battle of Ideas, Princeton, NJ, Princeton University Press.

Bundesministerium für Wirtschaft und Energie (2019) Fakten zum deutschen Außenhandel, accessed at https://www.bmwi.de/Redaktion/DE/Publikationen/Aussenwirtschaft/fakten-zumdeuschen-aussenhandel.html on February 10, 2020.

Burden, B. and oanberg, J. (2003) 'Budget rhetoric in presidential campaigns from 1952 to 2000', Political Behavior, 25, 97-118. 
Cerrato, A., Ferrara, F. M., and Ruggieri, F. (2018) 'Why Does Import Competition Favor Republicans?', paper presented at the 2018 APSA Annual Conference in Boston, available at: https://papers.ssrn.com/sol3/papers.cfm?abstract_id=3147169.

Chang, J., Gerrish, S., Wang, C., Boyd-Graber, J. L. and Blei, D. M. (2009) 'Reading Tea Leaves: How Humans Interpret Topic Models', Advances in Neural Information Processing Systems, 22, 288-296.

Chong, D. and Druckman, J. N. (2007) 'Framing Theory', Annual Review of Political Science, 10, 103-126.

Chwieroth, J. M. (2007) 'Testing and Measuring the Role of Ideas: The Case of Neoliberalism in the International Monetary Fund', International Studies Quarterly, 51, $5-30$.

Cross, J. and Greene, D. (2019) 'Talk Is Not Cheap: Policy Agendas, Information Processing, and the Unusually Proportional Nature of European Central Bank Communications Policy Responses.' Governance, 33, 425-444.

De Boef, S. and Kellstedt, P.M. (2004) 'The Political (and Economic) Origins of Consumer Confidence', American Journal of Political Science, 48, 633-649.

De Grauwe, P. (2011) The Governance of a Fragile Euro Area, CEPS Working Paper No. 346.

den Haan, W., Ellison, M., Ilzetzki, E., McMahon, M. and Reis, R. (2016) 'The Danger of Germany's Current Account Surpluses: Results of the CFM and CEPR Survey', accessed at https://voxeu.org/article/danger-germanys-current-account-surpluses-results-cfm-andcepr-survey on 27 March 2020.

Diessner, S. and Lisi, G. (2019) 'Masters of the 'Masters of the Universe'? Monetary, Fiscal and Financial Dominance in the Euro Area.' Socio-Economic Review, 18, 315-335.

Dieter, H. (2018) Stubbornly Germany First. Options for Reducing the World's Largest Current Account Surplus, Berlin, SWP Comment No. 48. 
European Commission (2016) Country Report Germany 2016 - Including an In-Depth

Review on the Prevention and Correction of Macroeconomic Imbalances, Commission Staff Working Document, accessed at https://ec.europa.eu/info/sites/info/files/cr2016_germany_en.pdf on January 10, 2019.

Fan, D. P. (1988) Predictions of Public Opinion from the Mass Media: Computer Content Analysis and Mathematical Modeling, Westport, Greenwood Press.

Ferrara, F. M. (2020) 'The Battle of Ideas on the Euro Crisis: Evidence from ECB InterMeeting Speeches', Journal of European Public Policy, 27, 1463-1486.

Ferrara, F. M. and Sattler, T. (2018) 'The Political Economy of Financial Markets.' Oxford Research Encyclopedia of Politics, July. DOI:

10.1093/acrefore/9780190228637.013.628

Financial Times (1988) 'Fifty Years of the D-Mark: Currency Has Become a Symbol of National Pride', London, p. 7 (June 24).

Flassbeck, H. and Lapavitsas, C. (2013) The Systemic Crisis of the Euro - True Causes and Effective Therapies, Rosa Luxemburg Stiftung Studien, accessed at https://www.rosalux.de/publikation/id/6773/the-systemic-crisis-of-the-euro-true-causesand-effective-therapies/ on January 08, 2019.

Frieden, J. A. (1991) 'Invested Interests: The Politics of National Economic Policies in a World of Global Finance', International Organization, 45, 425-451.

Gourinchas, P-O. and Rey, H. (2005) From World Banker to World Venture Capitalist: US External Adjustment and the Exorbitant Privilege, NBER Working Paper 11563, accessed at http://www.nber.org/papers/w11563 on January 16, 2019.

Haffert, L. (2019) 'Permanent Budget Surpluses as a Fiscal Regime', Socio-Economic Review, 17, 1043-1063.

Hall, P. A. and Soskice, D. W. (2001) Varieties of Capitalism: The Institutional Foundations of Comparative Advantage, Oxford, Oxford University Press. 
Hall, P. A. and Franzese, R. J. (1998) 'Mixed Signals: Central Bank Independence, Coordinated Wage Bargaining, and European Monetary Union', International Organization, 52, 505-535.

Hancké, B. (2013) Unions, Central Banks, and EMU: Labour Market Institutions and Monetary Integration in Europe, Oxford, Oxford University Press.

Haas P. M. (1992) 'Introduction: epistemic communities and international policy coordination', International Organization, 46, 1-35.

Harell, A., Soroka, S. N. and Iyengar, S. (2016) 'Race, prejudice and attitudes toward redistribution: A comparative experimental approach', European Journal of Political Research, 55, 723-744.

Hay, C. and Rosamond, B. (2002) 'Globalization, European Integration and the Discursive Construction of Economic Imperatives', Journal of European Public Policy, 9, 147-167.

Helgadóttir, O. (2016) 'The Bocconi boys go to Brussels: Italian economic ideas, professional networks and European austerity', Journal of European Public Policy, 23, 392-409.

Helleiner, E. and Kirshner, J. (2009) The Future of the Dollar, Ithaca, Cornell University Press.

Hübscher, E. (2018). The Clientelistic Turn in Welfare State Policy-Making: Party Politics in Times of Austerity. ECPR Press.

Hübscher, E., Kemmerling, A. and Sattler, T. (2015) 'Austerity for the Win? The Effect of Fiscal Consolidation on Political Support for the Government', paper presented at the Annual Meeting of the European Political Science Association, June 25-27, Vienna.

Hübscher, E., Sattler, T. and Truchlewski, Z. (2021) 'Voter Attitudes towards Fiscal TradeOffs: Evidence from Three European Countries", paper presented at the Conference on “The Politics of Macroeconomic Policies,' Max Planck Institute for the Study of Societies (MPIfG), January 14-15, available at: 10.13140/RG.2.2.31085.20962. 
Hübscher, E., Sattler, T. and Wagner, M. (2020) 'Voter Responses to Fiscal Austerity', British Journal of Political Science, online first, DOI: https://doi.org/10.1017/S0007123420000320.

Hume, D. (1752) Political Discourses, Edinburgh, Printed for A. Kincaid, and A. Donaldson. International Monetary Fund (2016) Germany Article IV Consultation, IMF Country Report 16/202, accessed at https://www.imf.org/external/pubs/ft/scr/2016/cr16202.pdf on January 18, 2019.

IWD (2020) Viele Jobs hängen am Export, accessed at https://www.iwd.de/artikel/viele-jobshaengen-am-export-459120/ on March 12, 2020.

Jacobs, T. and Tschötschel, R. (2019) 'Topic Models Meet Discourse Analysis: A Quantitative Tool for a Qualitative Approach.' International Journal of Social Research Methodology, 22, 469-485.

Jacoby, W. G. (2000) 'Issue Framing and Public Opinion on Government Spending', American Journal of Political Science, 44, 750-767.

Johnston, A. (2016) From Convergence to Crisis: Labour Markets and the Instability of the Euro, Ithaca, NY, Cornell University Press.

Johnston, A., Hancké, B. and Pant, S. (2014) 'Comparative Institutional Advantage in the European Sovereign Debt Crisis', Comparative Political Studies, 47, 1771-1800.

Jones, E. (2009) 'Shifting the Focus: The New Political Economy of Global Macroeconomic Imbalances', SAIS Review, 29, 61-73.

Jones, E. (2011) 'Macroeconomic Imbalances and the Sovereign Debt Crisis'. In Hubner, K. (ed) Europe, Canada, and the Comprehensive Economic and Trade Agreement, London, Routledge.

Jones, E. (2015) 'Getting the Story Right: How You Should Choose between Different Interpretations of the European Crisis (And Why You Should Care)', Journal of European Integration, 37, 817-832. 
Jones, E. (2016) 'Competitiveness and the European Financial Crisis'. In Caporaso, J. A. and Rhodes, M. (eds) The Political and Economic Dynamics of the Euro Area Crisis, Oxford, New York, Oxford University Press.

Kayser, M. A. and Leininger, A. (2015) 'Vintage Errors: Do Real-Time Economic Data Improve Election Forecasts?', Research \& Politics, 2, 1-11.

Keck M.E. and Sikkink K. (1998) Activists Beyond Borders: Advocacy Networks in International Politics. Ithaca, NY, Cornell University Press.

Kollmann, R., Ratto, M., Roeger, W., in't Veld, J. and Vogel, L. (2014) What drives the German current account? And how does it affect other EU member states?, DG ECFIN Economic Papers No. 516.

Krugman, P. (2016) 'Trade Deficits: These Times Are Different', Paul Krugman Blog, accessed at https://krugman.blogs.nytimes.com/2016/03/28/trade-deficits-these-timesare-different/ on January 25, 2019.

Lee, O. (2009) 'Devaluation: Ready, Steady, Devalue', accessed at http://www.euromoney.com/Article/2118801/Devaluation-Ready-steady-devalue.html on January 25, 2019.

Manger, M. and Sattler, T. (2020) 'The Origins of Persistent Current Account Imbalances in the post-Bretton Woods Era', Comparative Political Studies, 53, 631-664

Matthijs, M. and McNamara, K. (2015) 'The Euro Crisis' Theory Effect: Northern Saints, Southern Sinners, and the Demise of the Eurobond', Journal of European Integration, 37, 229-245.

McCombs, M. and Reynolds, A. (2009) 'How the News Shapes Our Civic Agenda'. In Jennings B., Zillmann, D. and Oliver, M. B. (eds) Media Effects, London, Routledge, pp. $1-16$.

McNamara, K. (1999) 'Consensus and Constraint: Ideas and Capital Mobility in European Monetary Integration', Journal of Common Market Studies, 37, 455-476. 
Micossi, S., D’Onofrio, A. and Peirce, F. (2018) On German External Imbalances, CEPS Policy Insights No. 2018/13.

Moschella, M. (2014) 'Monitoring Macroeconomic Imbalances: Is EU Surveillance More Effective than IMF Surveillance?', Journal of Common Market Studies, 52, 1273-1289.

Moschella, M., and Pinto, L. (2018) 'Central Banks' Communication as Reputation Management: How the Fed Talks Under Uncertainty’ Public Administration, 97, 513529.

Mun, T. (1986 [1664]) England's Treasure by Forraign Trade, Reprints of economic classics Fairfield, NJ, A.M. Kelley.

Obstfeld, M. (2012) 'Does the Current Account Still Matter?', American Economic Review, $102,1-23$.

Obstfeld, M. and Rogoff, K. S. (1996) Foundations of International Macroeconomics, Cambridge, MA, MIT Press.

Petty, R., Priester, J.R. and Briñol, P. (2009) 'Mass Media Attitude Change: Implications on the Elaboration Likelihood Model of Persuasion'. In Bryant, J., Zillmann, D. and Oliver, M. B. (eds) Media Effects. Advances in Theory and Research, London, Routledge, pp. $125-164$.

Pitchford, J. D. 1989. ‘A Sceptical View of Australia's Current Account and Debt Problem', Australian Economic Review, 22, 5-14.

Proksch, S.-O. and Slapin, J. B. (2009) 'How to Avoid Pitfalls in Statistical Analysis of Political Texts: the Case of Germany', German Politics, 18, 323-344.

Redeker, N. and Walter, S. (2020) 'We'd Rather Pay than Change the Politics of German Non-Adjustment in the Euro Area Crisis', The Review of International Organizations, 15, 573-599.

Regan, A. (2017) 'The Imbalance of Capitalisms in the Euro Area: Can the North and South of Europe Converge?', Comparative European Politics, 15, 969-990. 
Rho, S. and Tomz, S. (2017) 'Why Don't Trade Preferences Reflect Economic Self-Interest?' International Organization, 71, 85-108.

Roberts, M. E., Stewart, B. M. and Tingley, D. (2019) 'Stm: R Package for Structural Topic Models', Journal of Statistical Software, 91, 1-40.

Roberts, M. E., Tingley, D. and Airoldi, E. M. (2016) 'A Model of Text for Experimentation in the Social Sciences' Journal of the American Statistical Association, 111, 988-1003.

Rodrik, D. (2009) 'The Real Exchange Rate and Economic Growth', Brookings Papers on Economic Activity, 2008, 365-412.

Schmidt, V. A. (2002) 'Does Discourse Matter in the Politics of Welfare State Adjustment?', Comparative Political Studies, 35, 168-193.

Schmidt, V. A. (2008) 'Discoursive Institutionalism: The Explanatory Power of Ideas and Discourse', Annual Review of Political Science, 11, 303-326.

Schmidt, V. A. (2010) 'Taking Ideas and Discourse Seriously: Explaining Change through Discursive Institutionalism as the Fourth 'New Institutionalism'. European Political Science Review, 2, 1-25.

Sinn, H-W. (2014) 'Austerity, Growth and Inflation: Remarks on the Euro Area's Unresolved Competitiveness Problem', The World Economy, 37, 1-13.

Smith, A. (2003 [1776]) An Inquiry into the Nature and Causes of the Wealth of Nations, New York, Bantam Classics.

The Economist (2016, October 27) 'Aussie Rules: What Australia Can Teach the World', London.

Viner, J. (1948) 'Power versus Plenty as Objectives of Foreign Policy in the Seventeenth and Eighteenth Centuries', World Politics, 1, 1-29.

Walter, S. (2013) Financial Crises and the Politics of Macroeconomic Adjustments, Cambridge, Cambridge University Press. 
Walter, S., Ray, A., and Redeker, N. (2020) The Politics of Bad Options: Why the Euro Area's Problems Have Been So Hard to Resolve, Oxford, Oxford University Press.

Young, L., and Soroka, S. (2012) 'Affective news: The automated coding of sentiment in political texts', Political Communication, 29, 205-231. 
i Some identify global imbalances as an important cause of the Global Financial Crisis of 2007-08 (Brender and Pisani, 2010). Others suggest that imbalances within the Euro Area have been a crucial trigger of the Euro Area crisis (Baldwin and Giavazzi, 2015). US dissatisfaction over the large current account surpluses in other countries has been steadily growing during the past years and even turned into a major political conflict after the 2016 US presidential election.

ii These, among others, include fiscal policy, changes to depreciation rules, the valueadded tax, or the government's ability to influence wages via the legal framework.

iii Mercantilists recommend that countries run an external surplus by exporting more than they import. This strategy leads to an accumulation of foreign assets, which is seen as an effective strategy to increase a country's wealth.

iv For better readability, we will refer to the two perspectives simply as 'competitiveness perspective' and 'investment perspective' in the remainder of the text.

v As the example of trade policy shows, citizens find it difficult to assess the trade-offs that are associated with international economic flows (Rho and Tomz, 2017).

${ }^{v i}$ Intervening variables such as an individual's attitude and personal environment can mitigate the impact of media reporting on opinions (Petty, Priester and Briñol, 2009). People may choose to consume news that confirm their pre-existing beliefs and reject information that does not fit into their worldview (for an overview of the debate, see Barnes and Hicks, 2018). However, at least in the long term, media reporting can be expected to have a long-term effect on how the current account balance is interpreted.

vii The current account data comes from the IMF Balance of Payments Statistics.

viii The Sydney Morning Herald has a regional focus, but in order to ensure ideological variation, we have decided to include it nevertheless. The Age, the fourth quality newspaper and only alternative, is also regional.

${ }^{i x}$ For Die Welt, The Australian and the Sydney Morning Herald, we used LexisNexis. For the Süddeutsche Zeitung and the Australian Financial Review we resorted to Factiva. Finally, for the Handelsblatt, we retrieved data directly from the official website.

$x$ "\% exported" looks at the industry in which the respondent works, and reports what share of that industry is based on exports (based on SITC codes).

${ }^{x i}$ Sophistication is measured by the main dimension of a principal component analysis of five sophistication questions. The left-right scale is a composite score of four questions on social policies reduced to one dimension using principal component analysis. The questions ask about support for (1) redistribution of wealth (2) state-ownership of public services and industries, (3) whether government should take responsibility to provide for individuals, and (4) whether people can only get rich at the expense of others.

xii The only exception is the first specification (i.e. the one without controls) of the ordered 
logistic model in Australia, where the difference between the estimated coefficients of the two treatments is statistically significant at the $10 \%$ level.

xiii E.g., the relative power of social coalitions. See, e.g., Haffert (2019). 